Edited by Robert C. Berring, under the guidance of a board of advisors consisting of experienced law librarians, the Legal Reference Services Quarterly is published by the Haworth Press, 149 Fifth Avenue, New York, N.Y. 10010, U.S.A.

The annual subscription rate in the United States is US\$ 40 for insituations and US\$25 for individuals. An additional postage fee of CS\$ 5 is required for Canadian orders. Foreign subscription rates are available on request.

\title{
NEWS FROM AUSTRALIA
}

This information is based on materials appearing in the Australian Law Librarians' Group Newsletter.

\section{Computerized Legal Research}

The Computerized Legal Information Committee of Victoria has issued a report on the establishment of computerized legal research services. Published in two volumes, the Report on Computerized Legal Information Retrieval in the State of Victoria is available for A $\$ 10$ and mailing costs from the Victoria Law Foundation Office, 160 Queen St., Melbourne, Vic. 3000, Australia.

Catalog Network

The Sydney Law Library Networking Committee has submitted a request for funds from the New South Wales Law Foundation to conduct a feasibility study on the establishment of a law catalog network.

\section{Communications Law Bulletin}

Commencing publication in April, 1981, this new quarterly is the official publication of the Australian Communications Law Association. Annual subscriptions are $A \$ 20$ for individuals and $A \$ 30$ for institutions. Subscriptions should be mailed to:

The Secretary

Australian Communications Law Association

c/-Faculty of Law

University of N.S.W.

P.O. Box 1

Kensington, N.S.W. 2033

AUSTRALIA

\section{Private Law Firm Libraries in Australia}

A survey of Australian private law firm libraries by Colin Fong, including a directory of such libraries and their librarians, is published in the Australian Law Librarians' Group Newsletter, No. 44, pp. 5-14 (July 1981). 
Colin Fong is the librarian at Allen, Allen \& Hemsley, a large and prestigious law firm in Sydney, which generously hosted a sumptuous luncheon for some of the participants of the IALL Australian Conference in May, 1981.

Travellers to Australia should make a point of visiting the library of Allen, Allen and Hemsley. It is located in a beautifully furnished semicircular space high up in one of the tallest buildings in the center of Sydney. The panoramic view of the Sydney Harbor and the Pacific Ocean from the library windows is spectacular.

\section{IALL Conference in Australia}

The 8th IALL Course on Law Librarianship, held in Sydney and Canberra in May, 1981, has been unanimously acclaimed by all of its participants as a great success. More detailed reports about the conference will appear in future issues of the journal. Conference papers will be published in a separate book, issued as a special IALL publication.

\section{HARVARD LEGAL BIBLIOGRAPHIES}

The prestigious Current Legal Bibliography and Annual Legal Bibliography of Harvard Law School Library ceased publication with Volume 21 of the Annual Legal Bibliography. This volume, cumulating the nine monthly issues of the Current Legal Bibliography, is now in the process of being distributed to subscribers.

The demise of this major bibliographic publication, considered by many a basic resource of legal research, does not necessarily mean that the legal community will be deprived of information about new law books and articles. Adequate information about periodical literature is already available from several index services which are successfully broadening their respective areas of coverage. With the aid of computers they are also becoming more efficient and expeditious in making information available to their users. Similar encouraging observations may be made about new books. Computerized cataloging networks offer speedy retrieval services for a broad range of books acquired by the participating libraries. Many of the major law libraries throughout the world, with a broad assortment of acquisitions extending beyond the confines of their respective national laws, regularly publish excellent lists of their newly acquired books. Newsletters of many national law library associations also contain valuable bibliographic information. Last but not least, there are numerous commercially-produced catalogs and lists of new publications.

There is no doubt that the Harvard legal bibliographies will be sorely missed, but the consequences need not be tragic. Most of the information which they contained is already available elsewhere, and such are the mysterious ways of economics that eventually the gap-whatever it may be 